\title{
Constraints Analysis of Cotton Growers during Adoption of IPM Practices for Control of Pink Bollworm
}

\author{
Shital Mane*, G. Sriker Reddy and Tarun Kumbhare \\ Department of Extension Education, College of Agriculture, Nagpur, India \\ *Corresponding author
}

\section{A B S T R A C T}

\begin{tabular}{|l|}
\hline Keyw or d s \\
Constraints, Cotton \\
growers
\end{tabular}

Cotton is a fibre and cashcrop. The present study on adoption of integrated pest management practices for control of pink bollworm by cotton growers with a sample size of 120 farmers selected from 10different villages of two talukas. In case of constraints all of the respondents expressed the major constraints such as lack of knowledge about use of trichocards $(100 \%)$, non availability of good quality of pheromone traps at proper time $(65.83 \%)$, lack of knowledge about selection of recommended variety with early medium maturity $(52.50 \%)$, high wages rate $(45.83 \%)$, lack of knowledge about spraying of Neem Seed Kernel Extract (43.33\%), lack of knowledge about application of chloropyriphos 20 ml/10lit. / quinolphos 20ml/10lit / profenophos $20 \mathrm{ml} / 10$ lit / thiodicarb $20 \mathrm{gm} / 10$ lit at initial stage of ETL (36.66\%), labours are not available at proper time $(35.83 \%)$, lack of knowledge about avoid mixing of agrochemicals $(35.00 \%)$ and high cost of insecticide $(33.33 \%)$, respectively.

\section{Introduction}

Cotton is important cash crop of India. It is also known as White Gold.According to first advanced estimate for 2017-18, the cotton acreage in Maharashtra will be 4.2 million hectares, compared with 3.8 million hectares last year. Of the total area under the fibre, about 1.3 million hectares are suspected to be infected with the PBW. Agriculture experts and farmers fear crop loss ranging from 50 to 80 per cent Vidarbha district.

Integrated Pest Management is a pest management system hat in the content of the associated environment and the pest population dynamics of the pest species. Utilize all suitable techniques and methods in as compatible manner as possible and maintain the pest population at the level below these causing economic injury. This approach has been maintaining the agro-ecosystem. It has more relevant due to advantage like safely to environment, pesticide-free food commodities, low input based crop production.

\section{Materials and Methods}

The study was conducted in Nagpur district of Maharashtra State. Out of 14 talukas of Nagpur district namely, Hingna and Nagpur 
(Rural) talukas were purposively selected for the study. Five villages were selected purposively from each taluka considering the maximum area under cotton cultivation. Thus in total, ten villages were taken for the study and a total of 120 respondents were selected. The exploratory research design was used for the study.

The data were collected in face-to-face situation by the personal interview method with the help of structured interview schedule containing the questions on adoption of integrated pest management practices for control of pink bollworm.
The problems related to various aspects of adoption of integrated pest management practices for control of pink bollworm were identified by obtaining response of individual respondent. The relevant data in this regard has been presented in Table 1 .

It is depicted from Table 1 that in case of cultural method constraints, above half of the cotton growers were faced problem of lack of knowledge about selection of recommended variety with early medium maturity $(52.50 \%)$, lack of knowledge about timely sowing $(19.16 \%)$ and lack of knowledge about deep ploughing during summer (10.84\%), respectively.

Table.1 Distribution of respondents according to constraints faced by them in adoption of integrated pest management practices

\begin{tabular}{|c|c|c|c|}
\hline \multirow{2}{*}{$\begin{array}{l}\text { Sl. } \\
\text { No. }\end{array}$} & \multirow[t]{2}{*}{ Constraints } & \multicolumn{2}{|c|}{ Respondents $(\mathrm{n}=120)$} \\
\hline & & Frequency & Percentage \\
\hline A. & Cultural Method & & \\
\hline 1. & $\begin{array}{l}\text { Lack of knowledge about deep ploughing during } \\
\text { summer }\end{array}$ & 13 & 10.84 \\
\hline 2 & $\begin{array}{l}\text { Lack of knowledge about timely sowing (Avoid pre } \\
\text { monsoon sowing) }\end{array}$ & 23 & 19.16 \\
\hline 3 & $\begin{array}{l}\text { Lack of knowledge about selection of recommended } \\
\text { variety with early medium maturity ( } 140 \text { to } 160 \\
\text { days duration and resistance to sucking pest) }\end{array}$ & 63 & 52.50 \\
\hline B & Mechanical Method & & \\
\hline 4 & $\begin{array}{l}\text { Lack of knowledge about hand picking and } \\
\text { destruction of larvae. }\end{array}$ & 48 & 40.00 \\
\hline 5 & $\begin{array}{l}\text { Lack of knowledge about destruction of cotton } \\
\text { stubbles immediate after by harvest. }\end{array}$ & 22 & 18.34 \\
\hline 6 & $\begin{array}{l}\text { Lack of knowledge about use of pheromone traps } \\
\text { ( } 2-3 \text { pheromone traps/acer) for monitoring. } \\
\text { (at the time of flowering) }\end{array}$ & 46 & 38.34 \\
\hline $\mathbf{C}$ & Biological Method & & \\
\hline 7 & $\begin{array}{l}\text { Lack of knowledge about spraying of Neem Seed } \\
\text { Kernel Extract (N.S.K.E.) } 5 \% \text { during flowering } \\
\text { stage. }\end{array}$ & 52 & 43.33 \\
\hline 8 & $\begin{array}{l}\text { Lack of knowledge about use of trichocards } \\
\text { ( } 3 \text { cards/acre) i.e. for } 7-8 \text { times after the initiation of } \\
\text { flowers at an interval } 8-10 \text { days. }\end{array}$ & 120 & 100.00 \\
\hline
\end{tabular}




\begin{tabular}{|c|c|c|c|}
\hline D & Chemical Method & & \\
\hline 9 & $\begin{array}{l}\text { Lack of knowledge about application of } \\
\text { chloropyriphos } 20 \mathrm{ml} / 10 \text { lit. / quinolphos } 20 \mathrm{ml} / 10 \mathrm{lit} \\
\text { / profenophos } 20 \mathrm{ml} / 10 \text { lit / thiodicarb } 20 \mathrm{gm} / 10 \mathrm{lit} \\
\text { at initial stage of ETL. }\end{array}$ & 15 & 12.50 \\
\hline 10 & $\begin{array}{l}\text { Lack of knowledge about avoid mixing of } \\
\text { agrochemicals. (Monocrotophos + Acephate) }\end{array}$ & 42 & 35.00 \\
\hline 11 & $\begin{array}{l}\text { Lack of knowledge about use of synthetic } \\
\text { pyrethroides (Cypermetherium } 10 \mathrm{ml} / 10 \text { lit and } \\
\text { Fenvelrate } 8 \mathrm{ml} / 10 \mathrm{lit} \text { and combination } \\
\text { product(During boll formation stage) }\end{array}$ & 44 & 36.66 \\
\hline $\mathbf{E}$ & Others & & \\
\hline 12 & Labours are not available at proper time. & 43 & 35.83 \\
\hline 13 & High cost of insecticides. & 40 & 33.33 \\
\hline 14 & High wages rate. & 55 & 45.83 \\
\hline 15 & $\begin{array}{l}\text { Non availability of good quality of pheromone traps } \\
\text { at proper time }\end{array}$ & 79 & 65.83 \\
\hline 17 & Non availability of trichocards at proper time & 120 & 100.00 \\
\hline
\end{tabular}

Constraints regards to mechanical method, majority of respondents $(40.00 \%)$ faced constraint lack of knowledge about hand picking and destruction of larvae, lack of knowledge about use of pheromone traps (2-3 pheromone traps/acer) for monitoring $(38.34 \%)$ and lack of knowledge about destruction of cotton stubbles immediate after by harvest $(18.34 \%)$, respectively.

As regards to biological method, major constraints faced by cotton growers $(100.00 \%)$ were lack of knowledge about use of trichocards (3cards/acre) i.e. for 7-8 times after the initiation of flowers at an interval 810 days and lack of knowledge about spraying of Neem Seed Kernel Extract (N.S.K.E.) 5\% during flowering stage (43.33\%), respectively.

In case of chemical method, constraints faced by cotton growers were lack of knowledge about use of synthetic pyrethroides (Cypermetherium $10 \mathrm{ml} / 10$ lit and Fenvelrate $8 \mathrm{ml} / 10 \mathrm{lit}$ ) and combination product (36.66\%), lack of knowledge about avoid mixing of agrochemicals (35.00\%) and lack of knowledge about application of chloropyriphos 20ml/10lit./quinolphos $20 \mathrm{ml} / 10$ lit/profenophos $20 \mathrm{ml} / 10$ lit/ thiodicarb $20 \mathrm{gm} / 10$ lit at initial stage of ETL (12.50\%), respectively.

With regards to other constraints majority of the respondents faced with problem like, non availability of trichocards at proper time $(100.00 \%)$, non availability of good pheromone traps at proper time $(65.83 \%)$ high wages rate $(45.83 \%)$, labours are not available at proper time $(35.83 \%)$ and high cost of insecticide (33.33\%), respectively.

The present findings incomplete / partial is in conformity with the findings reported by Shinde (2011), Zanjar (2011), Archana Jadhav (2017) and Rathawa (2018).

In summing up the constraints analysis revealed that the constraints with regard to technical constraints i.e. lack of knowledge emerged as important constraint. In order to reduce the attack of pink bollworm in cotton, the constraints experienced by the respondents with the regards to biological of 
vital importance and methods also can not be over looked.

By and large, it could be concluded that the analysis of these constraints emphasize to have concerted efforts to overcome these constraints so as to maximize the production of cotton and ultimate benefit to the farming community.

\section{References}

Archana Jadhav, 2017.Impact of crop pest surveillance and advisory project on beneficiary farmers. M.Sc. (Agri.)
Thesis (Unpub.), Dr. PDKV, Akola.

Rathwa,Y.H.2018. Knowledge and attitude of cotton growers towards integrated pest management in Surendranagar district of Gujrat state. M.Sc. (Agri.) Thesis (Unpub.), JAU, Junagadh

Shinde,V.J.2011. Attitude of cotton growers towards integrated pest management .M.Sc. (Agri.) Thesis (Unpub.), AAU, Anand.

Zanjar, R. P.2011. Constraints faced by the cotton growers in adoption of integrated pest management. M.Sc. (Agri.) Thesis (Unpub.), MKV, Parbhani.

\section{How to cite this article:}

Shital Mane, G. Sriker Reddy and Tarun Kumbhare. 2020. Constraints Analysis of Cotton Growers during Adoption of IPM Practices for Control of Pink Bollworm. Int.J.Curr.Microbiol.App.Sci. 9(12): 2500-2503. doi: https://doi.org/10.20546/ijcmas.2020.912.296 